\title{
Zespót demielinizacyjny z obecnymi przeciwciałami anty-MOG. Opis przypadku
}

\section{Demyelinating syndrome with the presence of anti-MOG antibodies. A case report}

\author{
Agnieszka Wencel-Warot*(D), Paweł Kemnitz** (iD), Barbara Steinborn* (iD) \\ * Katedra i Klinika Neurologii Wieku Rozwojowego ul. Przybyszewskiego 49 60-355 Poznań \\ **Klinika Chorób Zakaźnych i Neurologii Dziecięcej, ul. Szpitalna 27/33 60-572 Poznań \\ DOI:10.20966/chn.2020.59.475
}

\section{STRESZCZENIE}

Proces demielinizacyjny to jedna z przyczyn występowania deficytów neurologicznych także w populacji dziecięcej. Nie jest to proces jednorodny i wymaga szczegółowej diagnostyki, również tej różnicowej. W niektórych przypadkach postawienie diagnozy wiąże się z wykonaniem wielu badań i długotrwałą obserwacją pacjenta. Jest to tym bardziej istotne, że dopiero postawienie właściwego rozpoznania jest związane z optymalną terapią pacjenta. W niniejszej pracy przedstawiono przypadek pacjentki, u której rozpoznano proces demielinizacyjny z obecnymi przeciwciałami anty-MOG.

Słowa kluczowe: Proces demielinizacyjny, stwardnienie rozsiane, przeciwciała anty-MOG, leczenie immunomodulacyjne
ABSTRACT

The demyelinating process is one of the causes of neurological deficits also in the pediatric population. It is not a homogeneous process and requires detailed diagnostics, including differential diagnosis. In some cases making a diagnosis involves carrying out many tests and prolonged observation of the patient. This is all the more important as only the correct diagnosis is associated with optimal patient therapy. This paper presents the case of a patient diagnosed with demyelination with anti-MOG antibodies present.

Key words: Demyelinating process, multiple sclerosis, anti-MOG antibodies, immunomodulatory treatment

\section{WSTĘP}

RGlikoproteina mieliny oligodendrocytów (myelin oligodendrocyte glycoprotein - MOG) występuje wyłącznie w ośrodkowym układzie nerwowym (OUN). Mimo, że stanowi zaledwie 0,5 \% mieliny, jej zewnętrzna lokalizacja w osłonce mielinowej powoduje, że staje się ona dogodną domeną dla przeciwciał wiążących i potencjalnym celem dla chorób z obecnymi autoprzeciwciałami [1]. Obecność przeciwciał anty-MOG u pacjentów z procesem demielinizacyjnym determinuje objawy kliniczne, przebieg choroby, odchylenia w badaniach dodatkowych oraz odpowiedź na terapię. Szczególnie ważne jest to w przypadku populacji pediatrycznej, bo właśnie u dzieci przeciwciała anty-MOG występują częściej niż u pacjentów dorosłych [2].

\section{OPIS PRZYPADKU}

Dziewczynka niespełna 5-letnia została przyjęta do szpitala $\mathrm{w}$ trybie pilnym $\mathrm{z}$ powodu zaburzeń równowagi występujących od około 3 dni. Pacjentka zgłaszała zawroty głowy i trudności z chodzeniem. W badaniu przedmiotowym pediatrycznym nie stwierdzono istotnych odchyleń, w badaniu neurologicznym stwierdzono z odchyleń: przymusowe ustawienie głowy w stronę prawą przy zachowaniu pełnej ruchomości odcinka szyjnego kręgosłupa, obecność oczopląsu przy patrzeniu ku górze i w stronę prawą.
Obecne było także drżenie zamiarowe w próbie palec-nos, nieprawidłowa próba Romberga. Chód był nieprawidłowy, ataktyczny ze zbaczaniem w stronę prawą.

Wykonano badania dodatkowe, w tym podstawowe badania laboratoryjne - wyniki prawidłowe, ultrasonografia (USG) jamy brzusznej - wynik prawidłowy, tomografia komputerowa (KT) głowy - obraz prawidłowy. Diagnostykę poszerzono o badanie rezonansu magnetycznego (MR) głowy. W badaniu tym stwierdzono obecność następujących zmian: - po stronie lewej w przedniej części półkuli móżdżku oraz w obrębie konara środkowego stwierdzono obecność obszaru podwyższonego sygnału w obrazach T2-zależnych i w sekwencji FLAIR wielkości 30 x 20 x 15 mm z dyskretnym modelowaniem komory IV. W obrazach T1-zależnych w opisywanej lokalizacji stwierdzono minimalne obniżenie sygnału. Opisywane ognisko nie wzmacniało się po podaniu kontrastu. Nie stwierdzono obecności innych zmian. Według opisującego badanie radiologa obraz mógł odpowiadać astrocytoma bądź hamartoma. Zastosowano leczenie przeciwobrzękowe, przeciwwirusowe i przeciwbakteryjne, obserwowano stopniowe zmniejszanie objawów. Z uwagi na wynik badania MR i podejrzenie procesu rozrostowego pacjentka została przekazana do Oddziału Neurochirurgii, gdzie ostatecznie z uwagi na niespecyficzny obraz zmiany nie została zakwalifikowana do 
leczenia operacyjnego. W stanie ogólnym dobrym dziewczynka została wypisana do domu z zaleceniem wykonania badań kontrolnych.

Pierwsze kontrolne badanie MR głowy wykonano po 3 miesiącach - stwierdzono niemal całkowitą remisję zmiany (w miejscu opisywanego ogniska stwierdzono obecność obszaru minimalnie podwyższonego sygnału w sekwencji T2 wielkości $17 \mathrm{~mm}$, bez wzmocnienia po podaniu kontrastu i nie powodującego efektu masy) - wobec powyższego wysunięto podejrzenie tła zapalnego zmiany. Kolejne badanie obrazowe wykonano po 7 i następnie 14 miesiącach - obraz prawidłowy. Pacjentka i rodzice nie zgłaszali występowania niepokojących objawów, nie stwierdzono także odchyleń w badaniu przedmiotowym.

\section{Ryc 1 - X 2016}

Po stronie lewej w móżdżku, na wysokości odnogi lewej móżdżku widoczne jest nieregularne ognisko hiperintensywne o całkowitej dł. ok. 16mm, które może odpowiadać zmianie demielinizacyjnej. Zmiana sięga ku dołowi, na wysokości pogranicza mostu i rdzenia przedłużonego.

On the left side of the cerebellum, at the height of the left cerebellar peduncle, an irregular hyperintensive focus with a total length of about $16 \mathrm{~mm}$ is visible, which may correspond to a demyelinating lesion. The change reaches downwards, at the border area between the height of pons and the medulla oblongata.

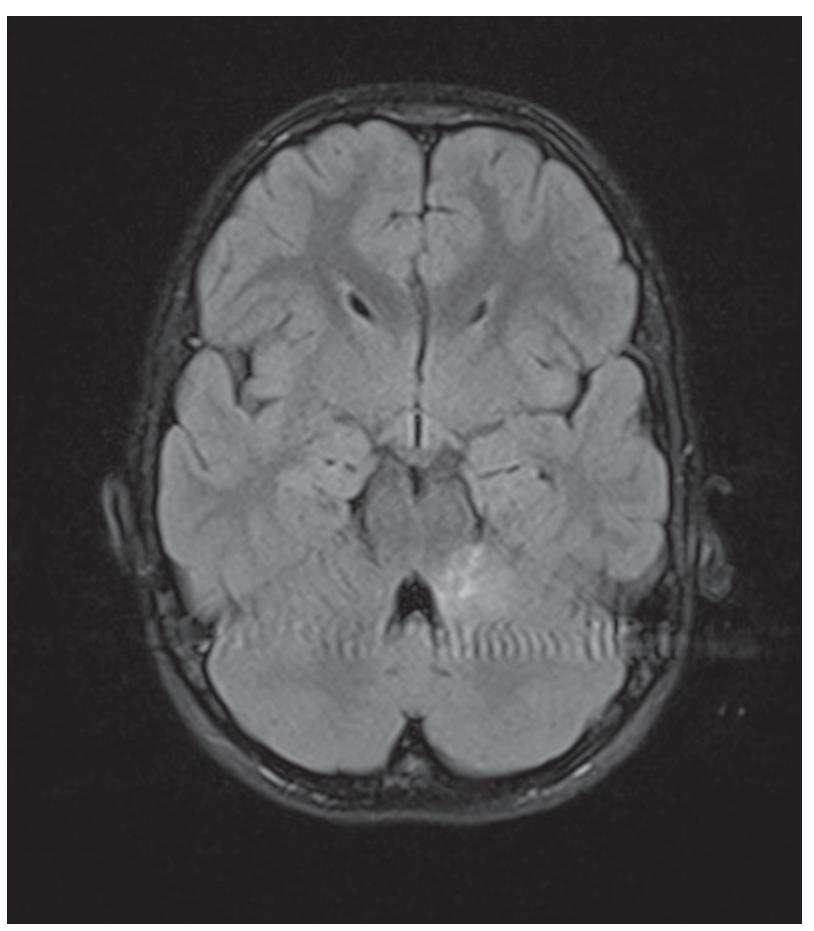

Po około 2,5 letnim okresie od wystąpienia pierwszego incydentu dziewczynka zgłosiła się do szpitala pediatrycznego z powodu wystąpienia ponownych objawów zawrotów głowy z towarzyszącymi wymiotami oraz niepewnego chodu. Początkowo podejrzewano infekcję wirusową przewodu pokarmowego, z uwagi jednak na nawrót dolegliwości po początkowej poprawie i ustępowaniu dolegliwości po podaniu leków przeciwobrzękowych (zastosowano terapię Dexavenem i Mannitolem) przekazano dziewczynkę celem dalszej diagnostyki do Oddziału Neurologicznego. Przy przyjęciu dziewczynka nie zgłaszała już objawów, nie stwierdzono także odchyleń w badaniu przedmiotowym. Diagnostykę pogłębiono o badanie rezonansu magnetycznego głowy - obraz prawidłowy.

\section{Ryc 1 - X 2016}

Po stronie lewej w móżdżku, na wysokości odnogi lewej móżdżku widoczne jest nieregularne ognisko hiperintensywne o całkowitej dł. ok. 16mm, które może odpowiadać zmianie demielinizacyjnej. Zmiana sięga ku dołowi, na wysokości pogranicza mostu i rdzenia przedłużonego.

On the left side of the cerebellum, at the height of the left cerebellar peduncle, an irregular hyperintensive focus with a total length of about $16 \mathrm{~mm}$ is visible, which may correspond to a demyelinating lesion. The change reaches downwards, at the border area between the height of pons and the medulla oblongata.

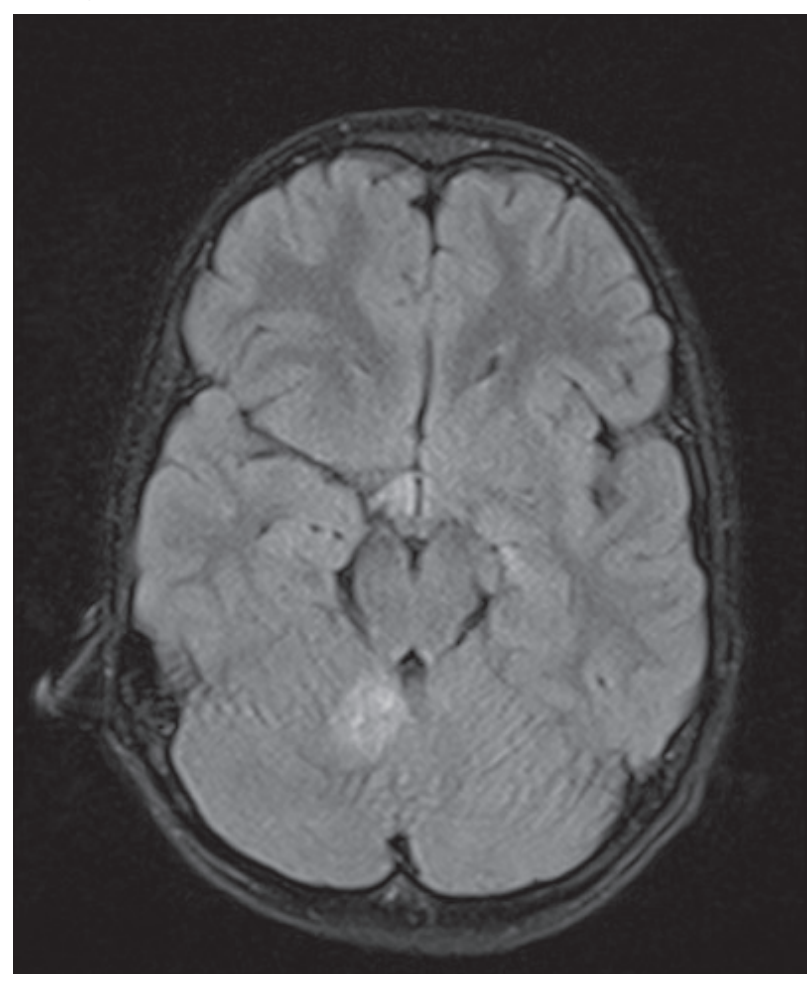

Kolejny incydent o podobnej morfologii (zaburzenia równowagi z towarzyszącymi zawrotami głowy) wystąpił po 11 miesiącach. W wykonanym badaniu rezonansu magnetycznego głowy stwierdzono obecność licznych ognisk hiperintensywnych w obrazach T2 i PD-zależnych oraz w sekwencji FLAIR widocznych w istocie białej półkul mózgowych, wzgórzach, w pniu mózgu oraz odcinku szyjnym rdzenia kręgowego, nie wykazujące efektu masy - najprawdopodobniej o charakterze ognisk demielinizacyjnych. Wobec powyższego pogłębiono diagnostykę o badanie płynu mózgowo-rdzeniowego - cytoza 24 przy prawidłowym stężeniu białka, prawidłowy indeks IgG, nie stwierdzono obecności prążków oligoklonalnych. Dodatkowo odbyła się konsultacja okulistyczna - w badaniu wzrokowych potencjałów wywołanych (WPW) stwierdzo- 
no niską amplitudę załamka P100, znacznie wydłużoną latencję, ponadto potwierdzono obustronnie ubytki włókien nerwów wzrokowych. Zdecydowano o terapii pulsami SoluMedrolu w dawce standardowej przez 5 dni, obserwowano całkowite ustąpienie objawów.

Po 3 miesiącach zdecydowano o kolejnej hospitalizacji celem wykonania badań kontrolnych (pacjentka nie zgłaszała wówczas żadnych objawów, ponownie w badaniu neurologicznym nie stwierdzono odchyleń). W kontrolnym badaniu MR głowy stwierdzono obecność nowych ognisk hiperintensywnych w sekwencjach FLAIR i T2-zależnych w moście po stronie prawej oraz w lewym płacie ciemieniowym. Ponadto stwierdzono mniejsze wysycenie ognisk opisywanych w badaniu poprzednim, nie uwidoczniono zmian na poziomie wzgórz obecnych w badaniu poprzednim. Diagnostykę uzupełnioną o badanie w kierunku przeciwciał przeciwko akwaporynie 4 - nieobecne, przeciwciała anty-gangliozydy w klasie IgM, ANA i ANCA - nieobecne, przeciwciała przeciwko Borrelia Burgdorferi - nieobecne. W kontrolnym badaniu okulistycznym stwierdzono obecność bladej tarczy n. II obustronnie od skroni, w badaniu WPW - poprawa parametrów zapisu , wydłużenie latencji załamka P100 obustronnie przy prawidłowej amplitudzie - obraz mogący odpowiadać zmianom o podłożu demielinizacyjnym. W trakcie hospitalizacji wystąpiły ponownie zawroty głowy z wymiotami - po wykluczeniu przyczyny gastroenterologicznej i wirusowej objawów na podstawie wywiadu i przeprowadzonej diagnostyki wysunięto podejrzenie rzutu stwardnienia rozsianego. Przeprowadzono terapię SoluMedrolem w dawce standardowej przez 5 dni uzyskując ustąpienie dolegliwości. Postawiono rozpoznanie stwardnienia rozsianego (sclerosis multiplex- SM) i skierowano pacjentkę na leczenie immunomodulacyjne.

W chwili kwalifikacji do terapii w badaniu neurologicznym nie stwierdzono odchyleń (punktacja w skali EDSS -0). Dziewczynka przyjmowała interferon beta 1a domięśniowo $1 \mathrm{x}$ w tygodniu. Po roku terapii wykonano kontrolne badanie MR głowy - nie stwierdzono obecności nowych ognisk. W trakcie kontrolnego badania okulistycznego stwierdzono znaczne pogorszenie ostrości widzenia oka lewego do dali i bliży nie poddające się korekcji okularowej, ponadto obustronnie blade tarcze nerwu wzrokowego (z przewagą strony lewej).

Po 16 miesiącach terapii ponownie wystąpiły zawroty głowy z nudnościami i wymiotami oraz zaburzenia równowagi. Dziewczynka zgłaszała także drętwienie lewej kończyny górnej i obu kończyn dolnych. W badaniu przedmiotowym neurologicznym stwierdzono obecność śladowego oczopląsu przy patrzeniu w stronę lewą, nieprawidłową próbę Romberga, chód ataktyczny, żywsze odruchy: kolanowy i skokowy po stronie lewej. W wykonanym w trybie pilnym badaniu MR głowy opisano na wysokości lewej odnogi móżdżku nieregularne ognisko hiperintesywne w obrazach T2 zależnych i sekwencji FLAIR o całkowitej długości około $16 \mathrm{~mm}$ sięgające pogranicza mostu i rdzenia przedłużonego, nie wzmacniające się po podaniu kontrastu. Nie opisano natomiast części zmian widocznych w badaniu poprzednim. W konsultacji okulistycznej potwierdzono neuropatię demielinizacyjną nerwów wzroko- wych obustronnie, dziewczynka nie rozpoznawała także barw badaniu tablicami Ishihary. Ponownie zastosowano terapię SoluMedrolem w dawce standradowej przez 5 dni uzyskując znaczną poprawę i ustąpienie objawów.

\section{Ryc 3 - X 2018}

Regresja opisywanych ognisk podnamiotowo Regression of the described foci infratentorially

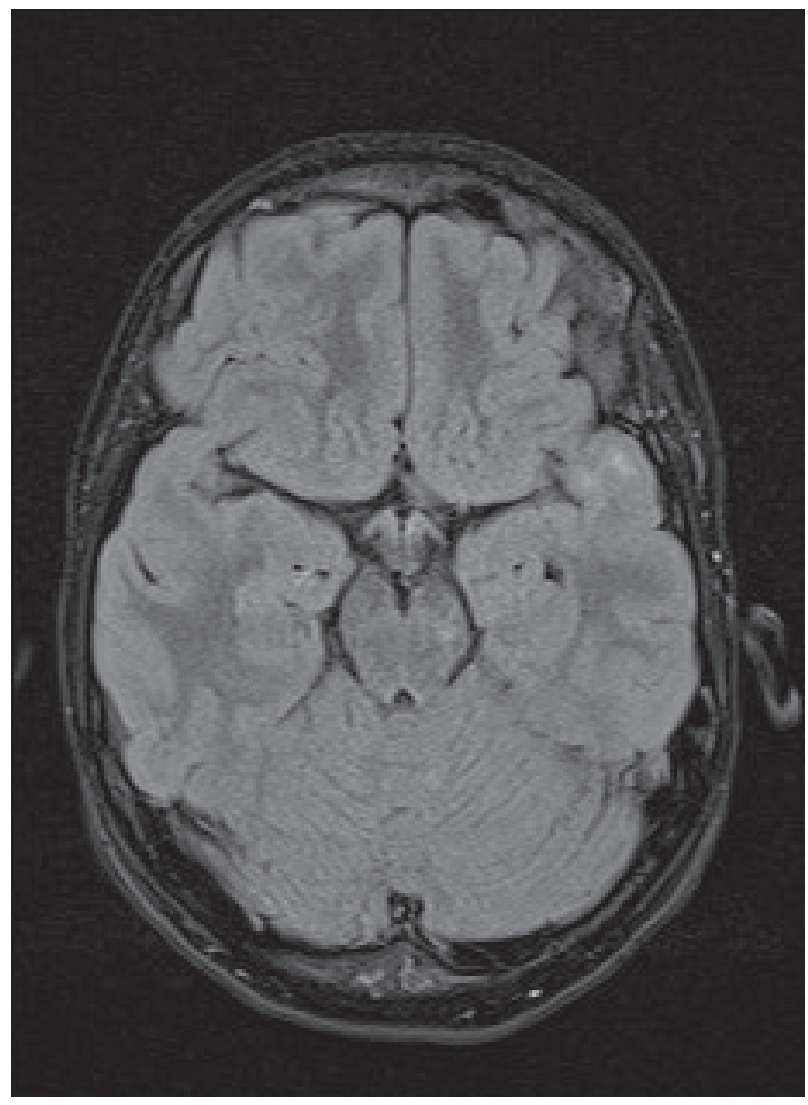

Objawy wystąpiły ponownie po 3 miesiącach o identycznej morfologii jak poprzednio. W badaniu przedmiotowym poza opisywanymi odchyleniami jak podczas poprzedniej hospitalizacji dodatkowo stwierdzono asymetrię odruchów brzusznych (słabsze po stronie lewej), nieznacznie obniżone napięcie mięśniowe w kończynach lewych oraz przejściową obecność objawu Rossolimo po stronie lewej. W wykonanym badaniu MR głowy stwierdzono obecność 3 nowych dużych ognisk demielinizacyjnych - w prawej półkuli móżdżku (wzmacniające się po podaniu kontrastu), rdzeniu przedłużonym oraz przykomorowo w prawej półkuli mózgu powyżej trzonu komory bocznej. Równocześnie stwierdzono regresję zmiany opisywanej w badaniu poprzednim w lewej półkuli móżdżku. Dodatkowo w badaniu MR odcinka szyjnego i piersiowego rdzenia kręgowego stwierdzono obecność dwóch zmian na poziomie Th4-Th5 na długości $12 \mathrm{~mm}$ i na poziomie Th7 na długości $10 \mathrm{~mm}$ hiperintensywnych w obrazach T2-zależnych odpowiadających ogniskom demielinizacyjnym. Ponownie przeprowadzono terapię SoluMedrolem z poprawą. Zdecydowano także o odstawieniu terapii interferonem z uwagi na wątpliwości diagnostyczne (wysunięte podejrzenie procesu demielinizacyjnego za spektrum neuromyelistis optica - NMO). 
Po kolejnych 4 i 8 miesiącach odbyły się kolejne hospitalizacje celem potwierdzenia rozpoznania. W badaniu przedmiotowym nie obserwowano wówczas badanych wcześniej odchyleń poza bladymi tarczami nerwów wzrokowych. Ponownie oznaczono przeciwciała przeciwko akwaporynie - nieobecne, nie stwierdzono obecności przeciwciał charakterystycznych dla celiakii, boreliozy, autoimmunologicznego zapalenia tarczycy. Nie stwierdzono obecności przeciwciał antykardiolipinowych, onkoneuronalnych, pANCA oraz cANCA, miano ANA - 1:160. Wykonano także spektroskopię rezonansu magnetycznego głowy - nie stwierdzono jednoznacznych zaburzeń poziomu metabolitów: NAA, choliny i kreatyny typowych dla SM. Ponadto przeprowadzono diagnostykę genetyczną $\mathrm{w}$ kierunku 3 mutacji w przebiegu neuropatii nerwu wzrokowego Lebera - wyniki prawidłowe.

Po kolejnych 18 miesiącach (dziewczynka miała wówczas 12 lat) została przyjęta do szpitala $\mathrm{z}$ powodu nasilenia osłabienia ostrości widzenia po stronie lewej potwierdzonego w trakcie konsultacji okulistycznej poprzedzonego bólem oka lewego, z podejrzeniem pozagałkowego zapalenia nerwu wzrokowego. W badaniu przedmiotowym neurologicznym nie stwierdzono nowych ubytków. Wykonano badanie MR głowy - obraz zmian był stabilny. Ponownie wykonano badania w kierunku obecności przeciwciał przeciwko akwaporynie 4 - nieobecne oraz wykonano badanie w kierunku obecności przeciwciał anty-MOG - potwierdzono ich obecność (badanie jakościowe metodą Elisa). Przeprowadzono terapię SoluMedrolem 1g/ dobę przez 5 dni uzyskując poprawę w zakresie ostrości widzenia. Zakwalifikowano także dziewczynkę do terapii immunoglobulinami. Przeprowadzono w sumie 6 kursów (każdy w dawce $2 \mathrm{~g} / \mathrm{kg} \mathrm{mc}$ ), nie obserwowano działań niepożądanych w trakcie leczenia. Wykonano kontrolne badania MR głowy i kręgosłupa, ostatnie 6 miesięcy po zakończonej terapii - obraz zmian stabilny. Nadal w badaniach laboratoryjnych stwierdzano obecność przeciwciał anty-MOG (badanie jakościowe). W badaniach okulistycznych stwierdzano poprawę, także w zakresie ostrości wzroku. Dziewczynka nie zgłaszała występowania niepokojących objawów.

\section{DYSKUSJA}

Kryteria rozpoznania stwardnienia rozsianego pozwalają na szybką diagnostykę pacjentów z podejrzeniem SM. Obecnie obowiązujące kryteria opublikowane w 2018 umożliwiają postawienie rozpoznania już po pierwszym epizodzie choroby, pod warunkiem udowodnienia rozsiania procesu zarówno w przestrzeni, jak i w czasie [3]. W przypadku pacjentów poniżej 18 roku obowiązują kryteria rozpoznania SM oparte o ustalenia grupy ekspertów z 2013 roku [4], potwierdzone w 2016 [5]. One także pozwalają na szybkie postawienie rozpoznania - tu także konieczne jest potwierdzenie rozsiania procesu zarówno w przestrzeni, jak i w czasie przy konieczności przeprowadzenia wnikliwej diagnostyki różnicowej. Eksperci zalecają szczególną ostrożność w stawianiu rozpoznania w przypadku pacjentów poniżej 12 roku życia $[4,5]$.
W przedstawionym opisie przypadku rozpoznanie SM postawiono po kolejnym epizodzie choroby i wobec obecności nowych ognisk demielinizacyjnych w kolejnych badaniach rezonansu magnetycznego, po przeprowadzeniu dostępnej, w chwili stawiania rozpoznania, diagnostyki różnicowej. Obecność jednak tzw. „czerwonych flag” - w tym nietypowego późniejszego przebiegu choroby, szczególnie zmian stwierdzanych w badaniach obrazowych kazały lekarzom opiekującym się pacjentką na weryfikację rozpoznania, biorąc pod uwagę możliwą inną przyczynę obserwowanych objawów i deficytów neurologicznych.

Przeciwciała anty-MOG według danych literaturowych wykrywane są u 18-35\% dzieci z objawami pierwszego ostrego epizodu demielinizacyjnego [6-8]. Są one częściej wykrywane u pacjentów z klinicznym obrazem ADEM, zapaleniem nerwu wzrokowego i nawracającym zapaleniem nerwu wzrokowego. Wydaje się być istotnym oznaczenie nie tylko jakościowe, ale przede wszystkim ilościowe przeciwciał anty MOG, z wynikiem miana 1:160 jako punktem odcięcia [7,9]. W badaniu Hennes i współpracowników z 2017 oznaczano obecność przeciwciał anty-MOG w grupie 210 dzieci $z$ nabytym zespołem demielinizacyjnym (acquired demyelinating syndromes - ADS)- w 60 przypadkach stwierdzono ADEM ( acute disseminated encephalomyelitis), w 12 NMOSD (neuromyelitis optica spectrum disorder), w 101 CIS (zespół izolowanych objawów - clinically isolated syndrome) i SM w 37 przypadkach. Przeciwciała anty-MOG w mianie $>1: 160$ były obecne w grupie 65 pacjentów z 210 badanych (31\%). Obecne były głównie u pacjentów z rozpoznaniem ADEM (57\%). W przypadku NMOSD i CIS stwierdzono je u $25 \%$ chorych, natomiast w przypadku SM zaledwie u $8 \%$ pacjentów. Większe miano przeciwciał związane był z młodszym wiekiem pacjentów, diagnozą ADEM, nieobecnymi prążkami oligoklonalnymi w badaniu płynu mózgowo-rdzeniowego oraz zwiększoną liczbą komórek w płynie mózgowo-rdzeniowym. W grupie badanej 79 pacjentów rozwinęło SM (ale tylko $4 \% \mathrm{w}$ grupie $\mathrm{z}$ obecnymi przeciwciałami anty-MOG). Wykazano także że, a miana $>1: 1280$ stanowiły prognostyk przebiegu choroby nie będącym SM. Takie miano odcięcia przeciwciał podnosiło specyficzność określenia przebiegu choroby jako nie-SM ( 96\% 1:160 do 100\% przy mianie 1:1280), jednak obniżało czułość oceny przebiegu choroby nie-MS z 47 do 31\% [10].

Podobne wyniki uzyskali Fernandez-Carbonell C i wsp. [11] , którzy zbadali grupę 74 pacjentów pediatrycznych hospitalizowanych w Massachusetts General Hospital z powodu podejrzenia procesu demielinizacyjnego. U 13 $(17,5 \%)$ z nich stwierdzono obecność przeciwciał anty-MOG i była to młodsza grupa pacjentów niż ta, u której nie stwierdzono obecności przeciwciał. Zauważono obecność 2 grup chorych - tych młodszych (4-8 letnich) z obrazem klinicznym encefalopatii i starszych, (13-18 letnich), u których dominowały objawy zapalenia nerwu wzrokowego. Przebieg polifazowy choroby obserwowano u 79,7\% pacjentów w grupie seronegatywnej i u 61,5\% w grupie chorych seropozytywnych. Jeśli chodzi o bada- 
nie laboratoryjne, stwierdzono wyższą liczbę komórek w badaniu płynu mózgowo rdzeniowego w grupie pacjentów z obecnymi przeciwciałami anty-MOG niż w grupie bez przeciwciał. W przypadku badania MR na pierwszy plan wysuwa się różnica jeśli chodzi o obecność zmian w ciele modzelowatym - stwierdzano ich obecność u 52\% pacjentów seronegatywnych i u żadnego z obecnymi przeciwciałami anty-MOG [11].

Hacohen Y. i wsp. [12]. opublikowali wyniki wieloośrodkowego badania europejskiego mającego na celu przedstawienie przebiegu choroby $\mathrm{i}$ odpowiedzi terapeutycznej u dzieci z rozpoznanym rzutowym procesem demielinizacyjnym $\mathrm{z}$ obecnymi przeciwciałami anty-MOG. Do uczestnictwa w badaniu zrekrutowano 102 pacjentów. U 44 z nich zdiagnozowano NMOSD (43,1\%), u 20 ADEM $\mathrm{z}$ kolejnym epizodem pod postacią zapalenia nerwu wzrokowego $(19,6 \%)$ lub wielofazowe rozsiane zapalenie mózgu i rdzenia (19,6\%). Z kolei nawracające zapalenie nerwu wzrokowego stwierdzono u 18 pacjentów (17,6\%). W sumie zaraportowano 464 epizodów demielinizacyjnych. U pacjentów powyżej 9 roku życia obserwowano objawy związane głownie z zapaleniem nerwu wzrokowego. Wśród 58 pacjentów, u których stwierdzono obecność nieprawidłowego badania MR głowy na początku choroby, u $50 \%$ obecne były objawy móżdżkowe. $\mathrm{Z}$ kolei w badaniu płynu mózgowo rdzeniowego podwyższona liczba limfocytów obecna była u 43 z 79 badanych pacjentów (58,9\%), natomiast obecność prążków oligoklonalnych stwierdzono jedynie u 6 z 54 badanych pacjentów $(11,1 \%)$. Co ciekawe, pacjenci leczeni mieli więcej rzutów niż ci bez leczenia (mediana 3 versus mediana 1) oraz osiągali wyższe wartości w skali EDSS (mediana 1,5 versus 1,0). W grupie dzieci leczonych 52 pacjentów otrzymywało leki immunomodulujące (28 leczonych było 1 lekiem, 172 lekami i 7 trzema lub więcej). Nie obserwowano różnicy istotnej statystycznie między efektami terapią interferonem a octanem glatirameru. Poprawę w zmniejszeniu liczby rzutów (redukcja rocznego wskaźnika rzutów z 2,16 na 0,51) oraz w skali EDSS (z 2,2 do 1,2$)$ obserwowano jedynie w grupie pacjentów leczonych regularnymi wlewami immunoglobulin [12].

Wyniki badania duńskiego opublikowane w 2019 [2], pokazały, że obecność przeciwciał anty-MOG stwierdzono u 92 pacjentów z 1227 przebadanych chorych (7\%). Większą seropozytywność stwierdzono w populacji dziecięcej $(0,31 / 100000)$ niż w populacji pacjentów dorosłych $(0,13 / 100000)$. W populacji dziecięcej najczęstszym fenotypem był ADEM (56\%), natomiast wśród osób dorosłych zapalenie nerwu wzrokowego (44\%). Rzutowy charakter choroby obserwowano u $26 \%$ pacjentów populacji dziecięcej i $41 \%$ pacjentów populacji osób dorosłych. W obserwacji długoterminowej wykazano, że 67\% pacjentów z przebiegiem monofazowym pozostaje seropozytwnymi. U większości pacjentów seronegatywnych nie obserwowano rzutów choroby (89\%) [2].

$\mathrm{W}$ przedstawionym przypadku pacjentki początkowo stwierdzano przede wszystkim objawy móżdżkowe, następnie deficyty związane $\mathrm{z}$ zapaleniem i neuropatią nerwu wzrokowego. Taki obraz kliniczny jest zgodny $z$ danymi literaturowymi $[11,12]$. Nie stwierdzano jednak w wywiadzie objawów ADEM, który jest najczęstszą manifestacją kliniczną procesu demielinizacyjnego z obecnymi przeciwciałami anty-MOG w młodszej grupie pacjentów [2,10-12] Badanie płynu mózgowego - liczba limfocytów 24 oraz brak obecności prążków oligoklonalnych są charakterystyczne dla pacjentów seropozytywnych $[11,12]$. Podobnie nietypowy obraz badania rezonansu, z rozmytymi ogniskami hiperintensywnymi, obecnością zmian w wzgórzach oraz w okolicy konarów móżdżku przy braku typowych ognisk w okolicy ciała modzelowatego (palców Dawson'a) może sugerować rozpoznanie procesu demielinizacyjnego $\mathrm{z}$ obecnymi przeciwciałami anty-MOG [13]. Z uwagi na początkowo rozpoznanie SM pacjentka została zakwalifikowana do terapii immunomodulacyjnej i zastosowano leczenie interferonem beta 1a im, które to okazało się nieskuteczne. Poprawę zaobserwowano dopiero po przeprowadzonej terapii wlewami immunoglobulin. W chwili obecnej takie postępowanie wydaje się być najskuteczniejszą terapią przewlekłą u pacjentów z obecnymi przeciwciałami anty-MOG i rzutami choroby [12]. Niewątpliwym ograniczeniem przedstawionego przypadku jest fakt, że przeciwciała anty-MOG zostały oznaczone jedynie jakościowo, a nie ilościowo. Jednak przebieg choroby, wyniki badań dodatkowych oraz odpowiedź na stosowane terapie wydają się potwierdzać stawiane rozpoznanie.

\section{PODSUMOWANIE}

Przedstawiony opis przypadku pacjentki z procesem demielinizacyjnym i obecnymi przeciwciałami anty-MOG przedstawia długoletni proces diagnostyczny i leczniczy, który ostatecznie zakończył się postawieniem właściwej diagnozy. Potwierdza on fakt, że czasami konieczna jest weryfikacja stawianego do tej pory rozpoznania. Szczególnie jest to istotne, gdy właściwe rozpoznanie związane jest $\mathrm{z}$ właściwym leczeniem. Błędne rozpoznanie stwardnienia rozsianego może doprowadzić do nieprawidłowo prowadzonej terapii i postępu niepełnosprawności pacjenta. Dlatego objawy będące tzw. „czerwonymi flagami” - w tym brak zadawalającej odpowiedzi na terapię mimo jej optymalnego stosowania oraz wyniki badań dodatkowych i przebieg kliniczny choroby sugerujący inną jednostkę niż SM zawsze powinny sugerować konieczność ponownej diagnostyki pacjenta [13].

\section{PIŚMIENNICTWO}

[1] Hemmer B., Archelos JJ., Hartung HP.: New concepts in the immunopathogenis of multiple sclerosis Nat. Rev. Neurosci. 2002; 3: 291-301.

[2] de Mol CL., Wong Y., van Pelt ED., et al.: The clinical spectrum and incidence of anti-MOG-associated acquired demyelinating syndromes in children and adults, Mult. Scler. 2019 May 16.

[3] Thompson A.J, Banwell B., Barkhof F., et al.: Diagnosis of multiple sclerosis: 2017 revisions of the McDonald criteria. Lancet Neurol. 2018; 17: $162-173$

[4] Krupp L.B, Tardieu M., Amato M.P., et al.: International Pediatric Multiple Sclerosis Study Group criteria for pediatric multiple sclerosis and immune-mediated central nervous system demyelinating disorders: revisions to the 2007 definitions" Mult. Scler. 2013; 19: 1261-1267. 
[5] Tardieu M., Banwell B., Wolinsky J.S., et al.: „Consensus definitions for pediatric MS and other demyelinating disorders in childhood" Neurology 2016; 87: S8-S11.

[6] Prőbstel AK, Dormair K., Bittner R. et al.: Antibodies to MOG are transient in childhood ADEM Neurology 2011; 77: 580-588.

[7] Hacohen Y., Absoud M., Deiva K. et al.: Myelin oligodendrocytes glycoprotein antibodies predict a non-MS demyelination course in children Neuroinflamm. 2015; 2: e81.

[8] Ketelslegers IA., VanPelt DE., Bryde S. et al.: „Anti-MOG antibodies plead against MS diagnosis in a acquired demyelinating syndromes cohort" Mult. Scler. 2015: 12: 1513-1520.

[9] Peschl P., Bradl M., Hoftberger R.,: Myelin oligodendrocyte glycoprotein: deciphering a target in inflammatory demyelinating diseases Front Immunol. 2017: 8: 529 .
[10] Hennes E.M., Baumann M., Schanda K., et al.: Prognostic relevance of MOG antibodies in children with an acquired demyelinating syndrome Neurology 2017; 89: 900-908.

[11] Fernandez-Carbonell C., Vargas-Lowy D., Musallam A., et al.: "Clinical and MRI phenotype of children with MOG antibodies" Mult. Sclr. 2016; 22: $174-184$.

[12] Hacohen Y., Wong YY. Lechner C. et al.: Disease course and treatment responses in children with relapsing myelin oligodendrocyte glycoprotein antibody - associated disease JAMA Neurol. 2018 Apr; 75: 478-487.

[13] Wynford-Thomas R., Jacob A., Tomassini V.: Neurological update: MOG antibody disease Journal of Neurology 2019; 266: 1280-1286. 